\title{
Comprehensive Review of Natural Convection Heat Transfer in Annulus Complex Enclosures
}

\author{
Ammar Abdulkadhim ${ }^{a *}$, Khaled Al-Farhany ${ }^{b}$, Azher M. Abed ${ }^{a}$, Hasan Sh. Majdi ${ }^{c}$ \\ ${ }^{a}$ Air conditioning and Refrigeration Techniques Engineering Department, Al-Mustaqbal University College, Babylon, 51001, Iraq \\ ${ }^{b}$ Department of mechanical engineering, University of Al-Qadisiyah, Al-Qadisiyah, Iraq. \\ ${ }^{c}$ Department of Chemical Engineering and Petroleum Industries, Al-Mustaqbal University College, Babylon, 51001, Iraq
}

\section{ARTICLE INFO}

\section{Article history:}

Received 01 March 2020

Received in revised form 26 April 2020

Accepted 30 April 2020

\section{Keywords:}

Natural convection

complex enclosures

Triangular

Trapezoidal

Parallelogrammic

Rhombic

Elliptical

\begin{abstract}
A B S T R A C T
The natural convection heat transfer has many applications in engineering like solar collectors, cooling of electronic equipment, and geothermal engineering. The present work demonstrates the recent publications in the last ten years in this specific subject for a body located in complex shapes like rhombic, wavy, trapezoidal, elliptical, and Parallelogrammic enclosure. Many parameters like $\mathrm{Ra}, \mathrm{Nu}$, number of undulations, the position of the inner body had been addressed and discussed to draw the main conclusions and recommendations. It is worthy to mention that a wavy enclosure has been investigated less than the other simple enclosure shapes due to its complexity. Besides that entropy generation should be included in future studies in complex shapes of enclosure as this will helps the researchers to extend their studies. The inner bodies inside trapezoidal, parallelogrammic enclosure are very limited, and more investigation should be done. The review concluded for the different shapes of enclosure with the tables that illustrate the major finding of each study. Finally, the governing equations of the natural convection of enclosure filled with pure fluid, porous medium, and nanofluid had been addressed.
\end{abstract}

(C) 2020 University of Al-Qadisiyah. All rights reserved.

\section{Simple Enclosures}

The natural convection heat transfer in simple enclosure shapes as illustrated in Fig. 1 had been studied numerically by various researchers due to its importance in energy related applications. Some of these studies were [1-20]. Ghasemi et al. [2] investigated numerically the influence of the magnetic field on buoyancy driven fluid flow in a square nanofluid enclosure filled with $\mathrm{Al}_{2} \mathrm{O}_{3}$-water. The results indicated that Rayleigh and Hartmann number had an opposite influence on heat transfer while the increasing of nanoparticle loading helps in augmentation of heat transfer.
Another important study focus on using a different model of nanofluid properties presented by Lai and Yang [3] using Lattice-Boltzmann scheme. They found that different methods of nanofluid properties affect the Nusselt number value. Bhuvaneswari et al. [4] computed using a finite volume approach the natural convection with the magnetic field in a square enclosure. The major of this study is that the authors applied sinusoidal temperature distribution to both of the sidewalls and keeping the horizontal wall adiabatic. The results indicated that increasing Hartmann number

* Corresponding author.

E-mail address: AmmarAbdulkadhim@mustaqbal-college.edu.iq (Ammar Abdulkadhim) 
reduces the heat transfer. Alam et al. [5] demonstrated the impact of aspect ratio and heat source power density on fluid flow circulation and heat transfer of free convection within rectangular enclosure heated and cooled partially from the vertical walls while the rest of them and others walls maintained adiabatic. They found that increases the aspect ratio augmented the heat transfer and it reaches its maximum value at aspect ratio equals to one. [6, 7] illustrated the double diffusive natural convection in tilted rectangular enclosure including the impact of a magnetic field and heat source. They concluded that heat source had a crucial impact on heat transfer. For more details about the previous works, the reader can be referring to [8-15]. Wang et al. [16] presented a comparison between the impact of $\mathrm{Al}_{2} \mathrm{O}_{3}-\mathrm{H}_{2} \mathrm{O}$ and $\mathrm{Ga}-\mathrm{H}_{2} \mathrm{O}$ and the radius under different Rayleigh numbers of heat transfer using a two-phase lattice Boltzmann method. The authors deduced that $\mathrm{Ga}-\mathrm{H}_{2} \mathrm{O}$ enhances the heat transfer better than $\mathrm{Al}_{2} \mathrm{O}_{3}$ $\mathrm{H}_{2} \mathrm{O}$. Al-Farhany and Abdulkadhim [17] examined the conjugate problem in a square enclosure filled with porous media under various Rayleigh and Darcy numbers and they obtained that wall thickness effects on the transformation of the heat mode from convection into conduction which reduces the heat transfer. Barik and Al-Farhany [21] studied the inflleucne of inclined baffle in nanofluid/porous square enclosure using COMSOL. Dutta et al. [18] studied the entropy generation in quadrant porous enclosure heated sinusoidally from its bottom wall. They concluded that entropy generation due to fluid friction is dominated at high values of Darcy number while they noticed the entropy formed due to heat transfer is the major influencer on low Darcy number. Torki and Etesami [19] experimentally studied the natural convection of a rectangular enclosure filled with $\mathrm{SiO}_{2}$ at different nanofluid loading and enclosure inclination angles. They obtained that the nanofluid did not affect low concentration value and the inclination angle of a rectangular enclosure had a strong effect. In addition, the Nusselt number is increased as the inclination angle goes up. Graževičius et al. [20] studied experimentally and numerically using ANSYS 17.2 of natural convection for removing heat from the reactor using a passive system. Also, the natural convection in complex shapes had been reported by various researchers like [22-25].

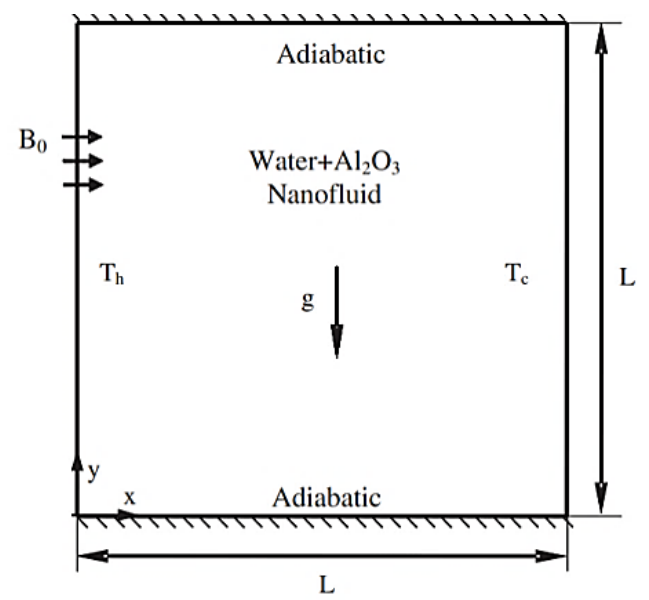

Figure 1. Schematic diagram of simple shape of enclosure (square) [2]
Sheikholeslami and Chamkha [22] examined the free convection in a liddriven enclosure filled with $\mathrm{Fe}_{3} \mathrm{O}_{4}$ with applied magnetic field and wavy wall. They obtained that increasing magnetic number, Rayleigh number, and nanofluid volume fraction increases the Nusselt number while Hartmann number had a reverse impact on Nusselt number. Sheikholeslami [23] studied the liquid metal due to natural convection in a wavy enclosure for various values of Rayleigh number, amplitude of wavy wall, and Hartmann number. It is worthy to mention here that the last parameters increasing lead to reduce the Nusselt number. Two important studies collect between MHD and wavy enclosure is presented in [24, 25] and they agreed with the previous mentioned results in the previous works of various researchers.

Besides that, various researchers dealt with the different shapes of an inner body located inside a regular simple enclosure shape like a square or rectangle that had been presented in Fig. 2. The inner body located within the enclosure had a wide range of applications like a solar collector, fuel cell, etc. The researchers among the world interested in understanding the effect of inner shapes like circular, triangular, elliptical, and wavy inside different shapes of the enclosure. Other researchers focus on the position of the inner body and change the direction vertically, horizontally and longitudinally. These are the main parameters that affect the heat transfer so that some of these studies are presented by [26-31]. Lee et al. [26] used an immersed boundary method to examine the changing of an inner cylinder located within square enclosure horizontally and longitudinally while another study by $[27,28]$ illustrates the vertical position on heat transfer. Ali et al. [29] studied the mixed convection due to rotating inner circular cylinder within square enclosure filled with air using ANSYS FLUENT. Roslan et al. [30] studied the heated circular cylinder located within the cold enclosure. The main important thing in this study is that the inner circular cylinder had sinusoidal temperature under unsteady conditions. We summarized the previous publications regarding the natural convection within simple shape, complex shapes and simple annulus enclosure in Table 1-3, respectively.

Finally, the present work concentrates on the inner body located inside the non-square enclosure.

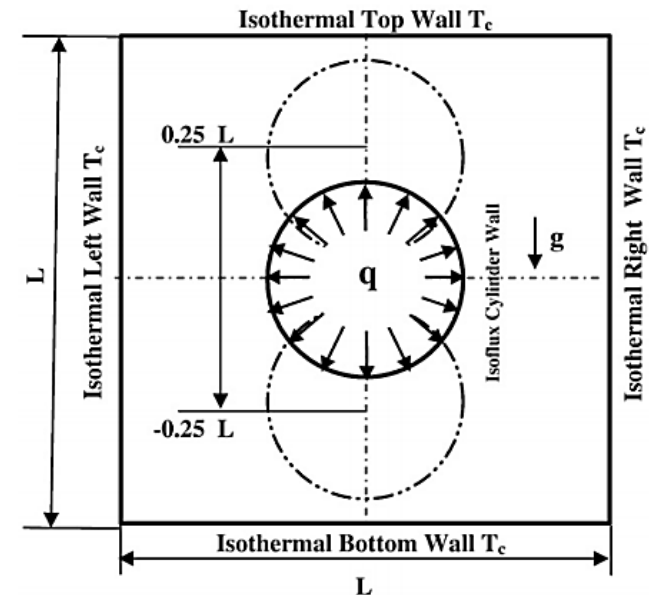

Figure 2. Schematic diagram of the inner body within simple enclosure shape [27] 
Table 1 summarized the studies of natural convection inside a simple shape of enclosure

\begin{tabular}{|c|c|c|c|c|c|}
\hline Ref & Objective & Enclosure shape & Software/model used & Conclusions & Special findings \\
\hline Ghasemi et al. [2] & $\begin{array}{l}\text { MHD and nanofluid } \\
\text { effect }\end{array}$ & Square & $\begin{array}{l}\text { CVM using SIMPLE } \\
\text { algorithm }\end{array}$ & $\begin{array}{l}\text { Hartmann and Rayleigh } \\
\text { numbers had an inverse } \\
\text { effect on Nusselt number }\end{array}$ & $\begin{array}{l}\text { Nanofluid effect may increases } \\
\text { of decreases Nusselt number } \\
\text { depending upon Rayleigh } \\
\text { number }\end{array}$ \\
\hline Lai and Yang [3] & Al2O3 nanofluid & Square & $\begin{array}{l}\text { Lattice - Boltzmann } \\
\text { method (LBM) }\end{array}$ & $\begin{array}{l}\text { Nanofluid thermophysical } \\
\text { models effect on the } \\
\text { computation of the Nusselt } \\
\text { number }\end{array}$ & $\begin{array}{l}\text { LBM is recommended for the } \\
\text { practical engineering } \\
\text { applications }\end{array}$ \\
\hline $\begin{array}{l}\text { Bhuvaneswari et } \\
\text { al. [4] }\end{array}$ & $\begin{array}{l}\text { Sinusoidal temperature } \\
\text { boundary conditions } \\
\text { with MHD effect }\end{array}$ & Square & FVM & $\begin{array}{l}\text { Increasing Hartmann } \\
\text { number reduces the heat } \\
\text { transfer }\end{array}$ & $\begin{array}{l}\text { The phase deviation of applied } \\
\text { Sinusoidal temperature effect } \\
\text { on Nusselt number }\end{array}$ \\
\hline Alam et al [5] & $\begin{array}{l}\text { Partial cooling/heating } \\
\text { and aspect ratio }\end{array}$ & Rectangle & FEM & $\begin{array}{l}\text { Nussselt number increases } \\
\text { when the aspect ratio range } \\
\text { from } 0.5-10 \text { beyond this } \\
\text { value it reduces } \mathrm{Nu} \text { as it } \\
\text { goes up. }\end{array}$ & $\begin{array}{l}\text { The maximum Nusselt number } \\
\text { is achieved at aspect ratio } \\
\text { equals to one. }\end{array}$ \\
\hline Teamah et al. [6] & $\begin{array}{l}\text { Double diffusive, } \\
\text { Inclinations angle, } \\
\text { MHD, buoyancy ratio }\end{array}$ & Inclined rectangle & $\begin{array}{l}\text { CVM SIMPLER } \\
\text { algorithm }\end{array}$ & $\begin{array}{l}\text { Lowest and Highest value } \\
\text { of Sherwood and } \mathrm{Nu} \\
\text { numbers were at } 75 \text { and } 150\end{array}$ & $\begin{array}{l}\text { Sherwood number is not } \\
\text { affected by heat absorption and } \\
\text { generation. }\end{array}$ \\
\hline El Qarnia et al. [9] & $\begin{array}{l}\text { Phase change due to } \\
\text { melting }\end{array}$ & Rectangle & FVM/FORTRAN & $\begin{array}{l}\text { Two correlations had been } \\
\text { developed. }\end{array}$ & $\begin{array}{l}\text { The developed model can be } \\
\text { used in phase change material }\end{array}$ \\
\hline $\begin{array}{l}\text { Nithyadevi et al. } \\
{[15]}\end{array}$ & $\begin{array}{l}\text { Effect of numbers of } \\
\text { discrete heater, Prandtl } \\
\text { number and heat } \\
\text { generation }\end{array}$ & Rectangle & FVM & $\begin{array}{l}\text { Increasing numbers of } \\
\text { heater and Prandtl number } \\
\text { enhance the heat transfer }\end{array}$ & $\begin{array}{l}\text { Increasing heat generation } \\
\text { reduces the heat transfer }\end{array}$ \\
\hline Qi at a;. [16] & $\mathrm{Ra}$ and nanofluid radius & Rectangle & Two-phase LBM & $\begin{array}{l}\text { Small radius of nanofluid } \\
\text { can enhance better than the } \\
\text { big size }\end{array}$ & $\begin{array}{l}\text { The augmentation of nanofluid } \\
\text { is better at low Ra number }\end{array}$ \\
\hline \begin{tabular}{|l|} 
Al-Farhany and \\
Abdulkadhim [17]
\end{tabular} & $\begin{array}{l}\text { Conjugate problem in } \\
\text { porous medium }\end{array}$ & square & FEM/COMSOL & $\begin{array}{l}\text { Increasing } \mathrm{Ra} \text { and } \mathrm{Da} \\
\text { enhance the heat transfer }\end{array}$ & $\begin{array}{l}\text { Increasing the conduction wall } \\
\text { reduces the heat transfer }\end{array}$ \\
\hline Dutta et al. [18] & $\begin{array}{l}\text { Porous media, entropy } \\
\text { generation with non- } \\
\text { uniform bottom wall } \\
\text { temperature }\end{array}$ & Quadrant & FEM & $\begin{array}{l}\text { Increasing Ra and Da } \\
\text { increase the heat transfer as } \\
\text { mentioned in most of the } \\
\text { publications }\end{array}$ & $\begin{array}{l}\text { When the Darcy number is } \\
\text { low, the heat transfer's entropy } \\
\text { generation is higher while at } \\
\text { the high Da, the entropy } \\
\text { generation due to friction of } \\
\text { fluids is higher }\end{array}$ \\
\hline Torki et al. [19] & $\begin{array}{l}\text { nanofluid, inclined } \\
\text { enclosure }\end{array}$ & Rectangle & Experimental study & $\begin{array}{l}\text { Increasing Rayleigh number } \\
\text { increases } \mathrm{Nu}\end{array}$ & $\begin{array}{l}\text { Inclination effect is higher at } \\
\text { low nanofluid loading }\end{array}$ \\
\hline
\end{tabular}

Table 2 summarized the studies of natural convection inside the complex shape of enclosure

\begin{tabular}{|l|l|l|l|l|l|}
\hline Ref & Objective & Enclosure shape & Software/model used & Conclusions & Special findings \\
\hline $\begin{array}{l}\text { Sheikholeslami } \\
\text { et al. [22] }\end{array}$ & $\begin{array}{l}\text { MHD, lid-driven } \\
\text { cavity, ferro nanofluid }\end{array}$ & Wavy & FEM/FORTRAN & $\begin{array}{l}\text { Increasing nanofluid } \\
\text { loading, Rayleigh, and } \\
\text { magnetic numbers } \\
\text { increases the heat } \\
\text { transfer while Hartmann } \\
\text { increases to reduce it. }\end{array}$ & $\begin{array}{l}\text { The authors studied the } \\
\text { wavy top wall which is a } \\
\text { little bit make a difference } \\
\text { with the previous } \\
\text { publications }\end{array}$ \\
\hline $\begin{array}{l}\text { Sheikholeslami } \\
\text { et al. [23] }\end{array}$ & MHD & Wavy & CVFEM & $\begin{array}{l}\text { Increasing Hartmann } \\
\text { number reduces Nu }\end{array}$ & $\begin{array}{l}\text { Hartmann number is highly } \\
\text { effects on fluid flow and } \\
\text { heat transfer }\end{array}$ \\
\hline $\begin{array}{l}\text { Xiong, et al. } \\
\text { [25] }\end{array}$ & $\begin{array}{l}\text { Nanofluid/porous } \\
\text { layers and MHD }\end{array}$ & Wavy & CVFEM & $\begin{array}{l}\text { Ha increasing leads to } \\
\text { reduction in the Nusselt } \\
\text { number }\end{array}$ & $\begin{array}{l}\text { Increasing Da leads to an } \\
\text { improvement in the heat } \\
\text { transfer }\end{array}$ \\
\hline
\end{tabular}


Table 3 summarized the studies of natural convection between inner body within regular (simple) enclosure shapes

\begin{tabular}{|l|l|l|l|l|l|}
\hline Ref & Objective & Enclosure shape & Software/model used & Conclusions & Special findings \\
\hline Lee et al. [26] & $\begin{array}{l}\text { Position of inner circular } \\
\text { cylinder in horizontal and } \\
\text { diagonal direction }\end{array}$ & $\begin{array}{l}\text { Circular cylinder } \\
\text { within square } \\
\text { enclosure }\end{array}$ & FVM & $\begin{array}{l}\text { Increasing Ra number leads } \\
\text { to enhance the Nusselt } \\
\text { number }\end{array}$ & $\begin{array}{l}\text { It is noted that when the } \\
\text { cylinder becomes closest to the } \\
\text { corner or left walls, the eddies } \\
\text { that located in the direction of } \\
\text { the cylinder will be separated } \\
\text { while one large eddies formed } \\
\text { behind the cylinder }\end{array}$ \\
\hline $\begin{array}{l}\text { Hussain and } \\
\text { Husssein [27] }\end{array}$ & $\begin{array}{l}\text { Vertical position of the } \\
\text { inner cylinder, constant } \\
\text { heat flux is considered } \\
\text { for the cylinder }\end{array}$ & $\begin{array}{l}\text { Circular cylinder } \\
\text { within square } \\
\text { enclosure }\end{array}$ & FVM & $\begin{array}{l}\text { When the cylinder moves } \\
\text { vertically upward, two inner } \\
\text { cells (eddies) are formed below } \\
\text { it. }\end{array}$ \\
\hline Park et al. [28] & Same the study of [27] except they applied isotherm hot temperature to the cylinder & $\begin{array}{l}\text { As Ra increases, Nu goes } \\
\text { up }\end{array}$ & $\begin{array}{l}\text { Increasing the oscillation of } \\
\text { the heat source leads to } \\
\text { improve the heat transfer. }\end{array}$ & $\begin{array}{l}\text { The frequency of wavy } \\
\text { condition } 25 \pi-30 \pi \text { augments } \\
\text { the heat transfer better }\end{array}$ \\
\hline [30] and [31] & Unsteady case study & $\begin{array}{l}\text { Wavy temperature } \\
\text { conditions inside a } \\
\text { square cavity }\end{array}$ & COMSOL & &
\end{tabular}

\section{Triangular enclosure}

This section describes different shapes of an inner body located inside a triangular enclosure. Schematic diagram of this case study is illustrated below in Fig. 3. Some of these studies presented by [32-38].

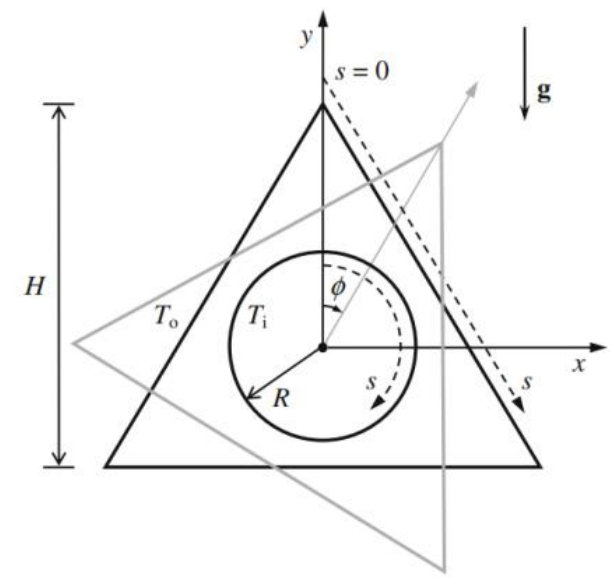

Figure 3. Schematic diagram of the inner body in a triangular enclosure [32]

$\mathrm{Xu}$ et al. [32] examined numerically the natural convection heat transfer between various shapes of the inner cylinder (circular, square, rhombic, and triangular) located inside the triangular enclosure tilted for various inclination angle. The inner cylinder is kept at uniform hot temperature while the triangular enclosure is cold. The governing equations had been solved numerically using a finite volume method and validated with the previously published work along the bottom wall. The results are crucial and indicate that increasing the Rayleigh numbers breaking down the symmetry of streamlines contours and concentrates the isotherms contours to the top between the gaps. Yu et al. [33] examined the influence of various values of Prandtl number on heat transfer between a circular cylinder located inside an inclined triangular enclosure. The equations of mass, energy, and momentum of fluid along with Boussinesq approximations had been solved using a finite volume scheme. The results indicate that a low Prandtl number less than 0.7 had no effect of fluid flow intensity and heat transfer while the inclination angle had strong effect on it. The authors proposed important empirical equations of Nusselt number in terms of Prandtl number. Selimefendigil and Öztop [34] examined the mixed convection between circular cylinder within right-angled triangular enclosure heated partially from its left vertical wall. The governing equations had been solved numerically using a finite element method. The results are important because of increasing Hartmann number reduces both of entropy generation and heat transfer while increasing nanofluid volume fraction and speed of rotating circular cylinder increases both of them. Yu et al. [35] studied the unsteady free convection between circular cylinder within triangular enclosure under various effects of Grashof number, aspect ratio (inner diameter), and inclination angle. They simulated this phenomenon using CFD code ANSYS Fluent 6.3 which is based upon a finite volume method. They developed a relation between Nusselt number as a function of Grashof number for different inner cylinder diameters and inclination angles. Wang et al. [36] examined the mixed convection within the different sizes of an inner rotating circular cylinder located within a triangular enclosure and the gap between them was filled with Ethylene glycol-silicon carbide nanofluid for different Rayleigh numbers. Fluent CFD code had been used to simulate the whole of this problem. The results of this paper agreed with the previously published works. Sourtiji et al. [37] examined the natural fluid flow between a circular cylinder within a triangular nanofluid enclosure using a control volume based on a finite element scheme. The nanofluid thermal thermo-physical properties like viscosity and thermal conductivity had been predicted using Brinkman and Maxwell-Garnetts. It is obtained that adding void fraction of nanofluid had a remarkable impact at low Rayleigh numbers. Also, it had been observed that increasing inner circular cylinder diameter augments the heat transfer obviously. Another important investigation had been reported in Amrani et al. [38]. The authors studied the combined effect of radiation as well as free convective flow for triangular enclosure within rectangular body. As the most of researchers, finite volume method had been used to simulate this phenomenon under various Rayleigh numbers and aspect ratios.

\section{Trapezoidal}

This section summarized the convection heat transfer due to the density difference between the inner body located within the trapezoidal enclosure [39-43]. Schematic representation of this case is presented in Fig. 4. 


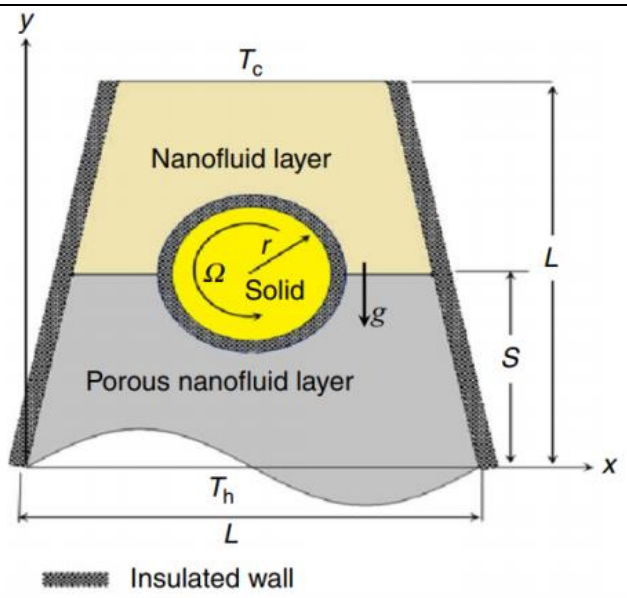

Figure 4. Schematic diagram of the inner body in a triangular enclosure [39]

Hussein et al. [39] investigated numerically the mixed convection heat transfer between the inner circular rotating cylinder immersed in the trapezoidal enclosure using COMSOL which is based upon the finite element scheme. The gap between the inner body and the enclosure is divided into two layers system; the upper layer is filled with Copper-water nanofluid while the lower layer is consisting of the same nanofluid immersed in a saturated porous medium. The authors studied the influences of many dimensionless parameters such as Rayleigh and Darcy numbers, nanofluid void fraction as well as many geometrical parameters such as undulations number of a bottom wavy wall, inner body's diameter and rotational speed and the thickness of the porous layer. The results were crucial and indicated that the increasing of Rayleigh, Darcy numbers, nanofluid void fraction, and inner body's diameter rotational leads to augmentation in the local Nusselt number, and that means enhancement of the heat transfer. However the behavior of other parameters is inverse which means as the layer of the porous medium and the number of undulations goes up, the heat transfer is reduced. Esam et al. [40] examined the natural convection heat transfer in a trapezoidal enclosure filled with multilayers using the finite element method. The enclosure is partially heated from the bottom wall while the top wall is kept at isotherm cold temperature. The two inclined walls, as well as the inner circular cylinder and the rest length of the bottom wall, are assumed adiabatic. The upper layer is filled with Ag-water nanofluid, while the lower layer filled with porous media saturated with the same nanofluid. The results had been validated with the previously published works and the agreement was good. The results indicate that increasing nanofluid, Darcy, and Rayleigh numbers increases the fluid flow intensity and the heat transfer rate. However, the behavior of porous layer thickness is completely reversed. Khan et al. [41] explained the mixed convection heat transfer between the inner heated circular cylinder rotating counter-clockwise located in a trapezoidal enclosure. The trapezoidal enclosure is kept adiabatic at its top and bottom wall while the two inclined walls are kept at cold temperatures. They made a comparison between the influence of the rotating cylinder and a motionless cylinder in a square enclosure. Their results confirmed that the rotating cylinder as well as the inclination angle of the sidewall effect significantly on the heat transfer. Selimefendigil [42] demonstrated numerically the natural convection between different shapes of the inner conductive body within a trapezoidal enclosure filled with different shapes of nanoparticle (blade, spherical, and cylindrical). The top and bottom walls are adiabatic while the left and right vertical walls are kept at isotherm hot and cold temperature respectively. The authors used finite element scheme to solve the governing equations and the validation seems good. The parameters of this study were Rayleigh number, thermal conductivity ratio, solid volume fraction, shapes of the nanoparticle and the inclination angle. It is worthy to mention that they conclude the shape of nanoparticle change obviously the heat transfer and the cylindrical shape is recommended for better Nusselt number and better enhancement in heat transfer. Ahmed et al. [43] visualized numerically using finite element techniques the heat lines in a nanofluid trapezoidal enclosure separated by a porous divider. The top wall is kept cold while a non-uniform temperature profile is applied to the bottom wall. The side walls are adiabatic. The parameters of this study are Rayleigh and Darcy number as well as nanofluid volume fraction as physical parameters. Also, many geometrical parameters had been investigated such as porous layer thickness and its positions as the authors moved it vertically upwards and downwards. The major findings were increasing the thickness of porous divider with the Rayleigh numbers augments the heat transfer. Also, the position of the porous divider is significant at low Rayleigh number while at higher Rayleigh number, the Nusselt number will be at the minimum values when the divider moved vertically downward.

We summarized the studies of the inner body within triangular and trapezoidal enclosure in Table 4.

Table 4 summarized the studies of natural convection between inner body within a triangular and trapezoidal enclosure

\begin{tabular}{|l|l|l|l|l|l|}
\hline Ref & Objective & Enclosure shape & $\begin{array}{l}\text { Software/ } \\
\text { model used }\end{array}$ & Conclusions & Special findings \\
\hline Xu et al. [32] & $\begin{array}{l}\text { Laminar free } \\
\text { lonvection, effect of } \\
\text { Ra, aspect ratio and } \\
\text { inclination angle }\end{array}$ & $\begin{array}{l}\text { Cylinder inside } \\
\text { triangular enclosure }\end{array}$ & CVM & $\begin{array}{l}\text { At constant aspect ratio, the } \\
\text { inclination angle and Ra effect } \\
\text { significantly on Nusselt number. }\end{array}$ & $\begin{array}{l}\text { Correlation of Nusselt number as a } \\
\text { function of Ra for each value of } \\
\text { aspect ratio }\end{array}$ \\
\hline Yu et al. [31] & $\begin{array}{l}\text { Effect of Prandtl } \\
\text { number }\end{array}$ & $\begin{array}{l}\text { Cylinder inside } \\
\text { coaxial triangular }\end{array}$ & FVM & $\begin{array}{l}\text { Inclination angle had a strong } \\
\text { impact on Nu }\end{array}$ & $\begin{array}{l}\text { Unique effect of low Prandtl } \\
\text { number Nu while when Pr } \geq 0.7 \text { it } \\
\text { does not affect Nu }\end{array}$ \\
\hline $\begin{array}{l}\text { Selimefendigil and } \\
\text { Öztop [34] }\end{array}$ & $\begin{array}{l}\text { Mixed convection, } \\
\text { MHD, nanofluid, }\end{array}$ & $\begin{array}{l}\text { Rotating insulated } \\
\text { cylinder inside } \\
\text { triangular enclosure }\end{array}$ & FEM & $\begin{array}{l}\text { Increasing nanofluid concentrations } \\
\text { and rotating lead to an increasing in } \\
\text { total entropy and Nusselt number }\end{array}$ & $\begin{array}{l}\text { to and Nuction in both the entropy } \\
\text { and Nuselt number }\end{array}$ \\
\hline Yu et al. [35] & $\begin{array}{l}\text { Unsteady natural } \\
\text { convection }\end{array}$ & $\begin{array}{l}\text { Cylinder inside } \\
\text { coaxial triangular }\end{array}$ & $\begin{array}{l}\text { ANSYS } \\
\text { Fluent }\end{array}$ & $\begin{array}{l}\text { Correlations of Nusselt number had } \\
\text { been developed. }\end{array}$ & $\begin{array}{l}\text { Nusselt number history had been } \\
\text { presented }\end{array}$ \\
\hline $\begin{array}{l}\text { Wang et al. Wang et } \\
\text { al. [36] }\end{array}$ & $\begin{array}{l}\text { Mixed convection, } \\
\text { nanofluid }\end{array}$ & $\begin{array}{l}\text { Cylinder inside } \\
\text { coaxial triangular }\end{array}$ & $\begin{array}{l}\text { ANSYS } \\
\text { Fluent }\end{array}$ & $\begin{array}{l}\text { Increasing Ra and nanofluid } \\
\text { volume fraction improve the Nu }\end{array}$ & $\begin{array}{l}\text { Rotational velocity effect } \\
\text { significantly on Nu }\end{array}$ \\
\hline
\end{tabular}




\begin{tabular}{|c|c|c|c|c|c|}
\hline Sourtiji et al. [37] & $\begin{array}{l}\text { Laminar buoyancy } \\
\text { driven flow, nanofluid }\end{array}$ & $\begin{array}{l}\text { Cylinder inside } \\
\text { triangular enclosure }\end{array}$ & CVFEM & $\begin{array}{l}\text { Nanoparticle improve the heat as } \\
\text { mentioned in most of the studies }\end{array}$ & $\begin{array}{l}\text { Maxwell-Garnetts (MG) and } \\
\text { Brinkman models had been used to } \\
\text { simulate the nanofluid presence }\end{array}$ \\
\hline Amrani et al. [38] & $\begin{array}{l}\text { Radiation and natural } \\
\text { convection effect }\end{array}$ & $\begin{array}{l}\text { Rectangle inside } \\
\text { triangular enclosure }\end{array}$ & FVM & $\begin{array}{l}\text { Decreasing the aspect ratio and } \\
\text { increasing the Ra number enhances } \\
\text { the heat transfer }\end{array}$ & $\begin{array}{l}\text { Thermal radiation promotes the heat } \\
\text { transfer }\end{array}$ \\
\hline Hussein et al. [39] & $\begin{array}{l}\text { Mixed convection with } \\
\text { multi-layer system }\end{array}$ & $\begin{array}{l}\text { Rotating cylinder in } \\
\text { trapezoidal enclosure } \\
\text { with sinusoidal } \\
\text { bottom wall }\end{array}$ & FEM & $\begin{array}{l}\text { The increasing the size and the } \\
\text { rotation speed of the inner cylinder } \\
\text { in addition to increases the } \mathrm{Da}, \mathrm{R} \\
\text { and nanofluid loading will improve } \\
\text { the heat transfer }\end{array}$ & $\begin{array}{l}\text { Increasing porous thickness and } \\
\text { number of undulation of the bottom } \\
\text { wall reduce the heat transfer }\end{array}$ \\
\hline Esam et al. [40] & $\begin{array}{l}\text { free convection with } \\
\text { multi-layer system }\end{array}$ & \begin{tabular}{|l|} 
Fixed adiabatic \\
cylinder within \\
trapezoidal enclosure
\end{tabular} & FEM & $\begin{array}{l}\text { The results indicate that increasing } \\
\mathrm{Ra}, \mathrm{Da} \text { and nanofluid loading } \\
\text { enhance the heat transfer }\end{array}$ & $\begin{array}{l}\text { Increasing porous thickness reduces } \\
\text { the heat transfer }\end{array}$ \\
\hline Khan et al. [41] & Mixed convection, air & $\begin{array}{l}\text { Rotating cylinder in } \\
\text { trapezoidal enclosure }\end{array}$ & FEM & $\begin{array}{l}\text { Grashof number for large } \\
\text { inclination angle is very strong }\end{array}$ & $\begin{array}{l}\text { Rotating speed of the inner cylinder } \\
\text { and inclination angle of the } \\
\text { trapezoidal wall effect highly on the } \\
\text { Nusselt number }\end{array}$ \\
\hline Selimefendigil [42] & $\begin{array}{l}\text { Natural convection } \\
\text { with different shapes of } \\
\text { nanoparticles (blades, } \\
\text { spherical and } \\
\text { cylindrical) } \\
\end{array}$ & $\begin{array}{l}\text { Different shapes of } \\
\text { inner body inside } \\
\text { trapezoidal }\end{array}$ & FEM & $\begin{array}{l}\text { Effect of Ra, thermal conductivity } \\
\text { ratio, nanofluid loading and shapes } \\
\text { of nanoparticle on Nu had been } \\
\text { discussed }\end{array}$ & $\begin{array}{l}\text { Cylindrical nanoparticle gives better } \\
\text { performance }\end{array}$ \\
\hline Ahmed et al. [43] & $\begin{array}{l}\text { Visualization of } \\
\text { heatlines of free } \\
\text { convection }\end{array}$ & $\begin{array}{l}\text { trapezoidal enclosure } \\
\text { divided by porous } \\
\text { medium partition }\end{array}$ & FEM & $\begin{array}{l}\text { Increasing Ra, nanofluid volume } \\
\text { fraction and Darcy number } \\
\text { augments the heat transfer }\end{array}$ & $\begin{array}{l}\text { Porous position equals to } 0.5 \text { gives } \\
\text { the better heat transfer }\end{array}$ \\
\hline
\end{tabular}

\section{Parallelogrammic}

This section summarized the convection heat transfer due to the density difference between the inner body located within the parallelogrammic enclosure [44-48]. The computational domain of these shapes is inserted in Fig. 5.

Hussein [44] investigated numerically the influence of the position of an inner circular cylinder located inside a parallelogrammic enclosure filled with air using a finite volume method. The inner circular cylinder is kept at a hot temperature while both vertical walls are cold. The top and bottom walls are adiabatic. The effect of Rayleigh number, the inclination angle of the vertical wall, and the inner circular cylinder position had been taken into account and examined their effect on fluid flow strength and the heat transfer. It was obtained that the maximum flow strength will be when the inclination angle is zero i.e., for square enclosure when the cylinder moves upwards by +0.1 . It was also obtained that when the cylinder moves downward will have greater Nusselt number than moving upwards. Majdi et al. [45] examined the natural convection between the hot circular cylinder immersed in a nanofluid parallelogrammic enclosure. The finite element had been used to solve the governing equations of heat transfer and fluid flow numerically. The validation was in good agreement with the previous publishing works. The results indicated that the increase of nanofluid volume fraction and Rayleigh number enhances the heat transfer especially if the inner circular cylinder moves vertically downwards until it reaches 0.1 .

Chamkha [46] examined numerically the conjugate (conductive-natural and forced) convection within the parallelogrammic enclosure separated by solid partition using the finite volume method. The influence of various parameters such as Richardson number, the inclination angle of the enclosure from the cavity left vertical wall as well as the thermal conductivity ratio. The results were crucial and all of the mentioned parameters affect the heat transfer rate. Baïri [47] used a finite volume scheme to simulate free convection under transient conditions within a parallelogrammic enclosure filled with air. The enclosure is partially heated from its left vertical wall while cold temperature conditions are applied to the right wall. The top and bottom walls are kept adiabatic. Hussain et al. [48] simulated the free convection in a parallelogrammic enclosure containing a volumetric source under various inclination angles. The enclosure is heated non-uniformly from its left wall while the right wall is at isotherm cold temperature. The top and bottom walls are adiabatic.

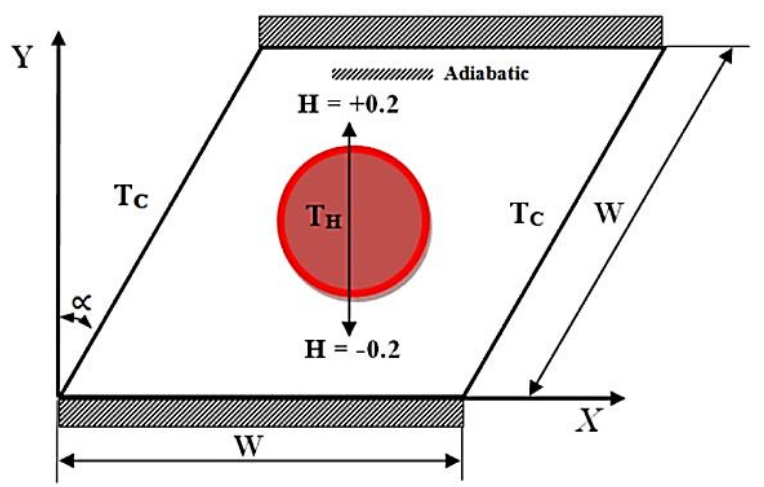

Figure 5. Schematic diagram of the inner body in a parallelogrammic enclosure [45]

\section{Rhombic}

This section summarized the convection heat transfer due to the density difference between the inner body located within rhombic enclosure [4953]. The present case is illustrated in Fig. 6.

Anandalakshmi and Basak [49] examined numerically the entropy generation and natural convection in a rhombic enclosure filled with saturated porous medium for different heating situation and inclination angle. Different uniform temperatures applied on the bottom and top walls where the bottom wall is warmer. Adiabatic conditions are considered to 
both inclined vertical walls. The finite element scheme had been used to solve the continuity, momentum, and energy equations. Choi et al. [50] demonstrated the position of an inner circular cylinder located within the rhombic enclosure subjected to transient conditions using the immersed boundary scheme. The simulation of this study was done under various dimensionless parameters, which are Rayleigh number and inner cylinder locations, which is changed vertically upwards and downwards. The results indicated that when the cylinder moves up, two circulations formed below it, and the Rayleigh number had a significant effect on the maps of streamlines and isotherms. Another important study was presented by Hosseinjani and Nikfar [51] focused on the natural convective fluid flow between two horizontal circular cylinders located within the nanofluid rhombic enclosure. The impact of symmetry, asymmetry, instability, and stability of $\mathrm{Cu}-\mathrm{O}$ nanofluid under various Rayleigh numbers had been explained. The impact of other parameters had been included such as diameter and the distance of inner cylinder, nanoparticle void fraction. The results reported that increasing the distance leads to an increase in transient asymmetric flow. Dogonchi et al. [53] investigated numerically the natural convection between the circular cylinder within a partially heated rhombic enclosure using CVFEM. The influence of nanoparticle shape factor, nanoparticle volume fraction, and had been examined. It is obtained the platelet shape had a better heat transfer rate.
The studies of the inner body within Parallelogrammic and Rhombic enclosure have been summarized in Table 5 .

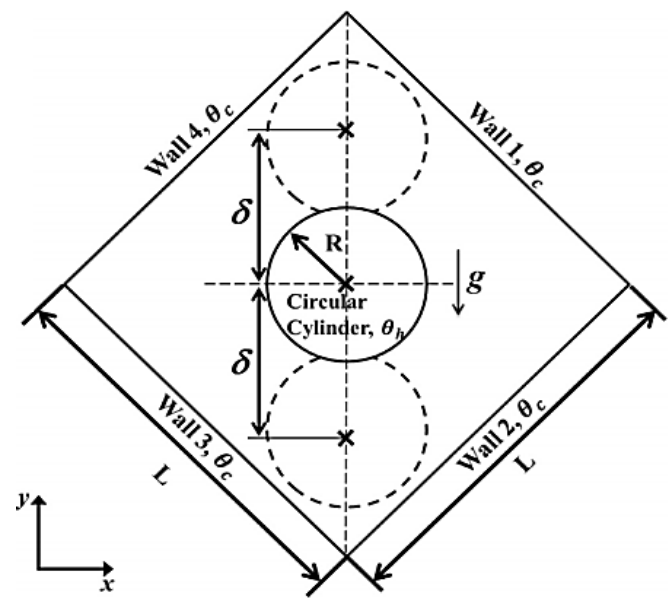

Figure 6. Schematic diagram of the inner body in a Rhombus enclosure [50]

Table 5 summarized the studies of natural convection between inner body within Parallelogrammic and Rhombic enclosure

\begin{tabular}{|c|c|c|c|c|c|}
\hline Ref & Objective & Enclosure shape & $\begin{array}{l}\text { Software/ } \\
\text { model used }\end{array}$ & Conclusions & Special findings \\
\hline Hussein [44] & $\begin{array}{l}\text { Natural convection in } \\
\text { Parallelogrammic } \\
\text { enclosure for different } \\
\text { vertical locations }\end{array}$ & $\begin{array}{l}\text { Cylinder inside } \\
\text { Parallelogrammic } \\
\text { enclosure filled } \\
\text { with air }\end{array}$ & FVM & $\begin{array}{l}\text { Increasing Ra leads to } \\
\text { enhance the heat transfer } \\
\text { and increases the fluid flow } \\
\text { strength. In addition, it is } \\
\text { recommended to incline the } \\
\text { vertical wall } 15 \text { for better } \\
\text { fluid strength. }\end{array}$ & $\begin{array}{l}\text { For better fluid flow strength and } \\
\text { heat transfer rate, it is } \\
\text { recommended to move the inner } \\
\text { cylinder towards the bottom wall } \\
\text { vertically }\end{array}$ \\
\hline Majdi et al. [45] & $\begin{array}{l}\text { Natural convection in } \\
\text { Parallelogrammic } \\
\text { enclosure for different } \\
\text { vertical locations }\end{array}$ & $\begin{array}{l}\text { Cylinder inside } \\
\text { Parallelogrammic } \\
\text { enclosure filled } \\
\text { with nanofluid }\end{array}$ & FEM & $\begin{array}{l}\text { Ra and nanofluid enhance } \\
\text { the heat transfer and fluid } \\
\text { flow strength }\end{array}$ & $\begin{array}{l}\text { Increasing inclination angle } \\
\text { enhances the heat transfer }\end{array}$ \\
\hline Chamkha [46] & Mixed convection & $\begin{array}{l}\text { Parallelogrammic } \\
\text { with solid partition }\end{array}$ & FVM & $\begin{array}{l}\text { The Thermal conductivity } \\
\text { ratio, Ri number, inclination } \\
\text { angle and the direction of } \\
\text { movement of the left } \\
\text { vertical wall upward and } \\
\text { downward effect on heat } \\
\text { transfer and fluid dynamics }\end{array}$ & $\begin{array}{l}\text { Mean skin friction coefficient } \\
\text { when the wall moves downward } \\
\text { was higher than if it moves } \\
\text { upward }\end{array}$ \\
\hline Baïri [47] & $\begin{array}{l}\text { Unsteady buoyancy in } \\
\text { buildings }\end{array}$ & $\begin{array}{l}\text { Parallelogrammic } \\
\text { enclosure filled } \\
\text { with air }\end{array}$ & FVM & $\begin{array}{l}\text { The influence of Ra number } \\
\text { and the slop of the building } \\
\text { effect on the building } \\
\text { cooling }\end{array}$ & $\begin{array}{l}\text { The authors presented data for } \\
\text { analysis of building including } \\
\text { fluid flow and heat transfer }\end{array}$ \\
\hline $\begin{array}{l}\text { Hussain et al. } \\
{[48]}\end{array}$ & $\begin{array}{l}\text { Free convection, heat } \\
\text { source with non- } \\
\text { uniform left sidewall }\end{array}$ & $\begin{array}{l}\text { Parallelogrammic } \\
\text { enclosure filled } \\
\text { with air }\end{array}$ & FVM & $\begin{array}{l}\text { Internal and external } \\
\text { Rayleigh number effect on } \\
\text { heat transfer. }\end{array}$ & $\begin{array}{l}\text { Increases inclination angle in } \\
\text { positive direction leads to a } \\
\text { reduction in fluid flow strength } \\
\text { while when it increases in the } \\
\text { negative direction; the fluid flow } \\
\text { circulation becomes larger. }\end{array}$ \\
\hline $\begin{array}{l}\text { Anandalakshmi } \\
\text { and Basak [49] }\end{array}$ & $\begin{array}{l}\text { Free convective flow } \\
\text { with entropy } \\
\text { generation with two } \\
\text { different locations } \\
\text { (cases) of the heat } \\
\text { sources }\end{array}$ & $\begin{array}{l}\text { Rhombic filled } \\
\text { with porous } \\
\text { medium }\end{array}$ & FEM & $\begin{array}{l}\text { Rhombic with inclination } \\
\text { angle } 30 \text { is recommended to } \\
\text { usage as it gives minimum } \\
\text { entropy generation. } \\
\text { However, it gives less heat } \\
\text { transfer enhancement }\end{array}$ & $\begin{array}{l}\text { Case } 1 \text { is better in energy } \\
\text { efficiency compared to case } 2 \text { as } \\
\text { the latter produces much } \\
\text { irreversibility more than case } 1\end{array}$ \\
\hline
\end{tabular}




\begin{tabular}{|c|c|c|c|c|c|}
\hline Choi et al. [50] & $\begin{array}{l}\text { Impact of inner } \\
\text { position of circular } \\
\text { cylinder on heat } \\
\text { transfer under } \\
\text { transient state. }\end{array}$ & $\begin{array}{l}\text { Rhombus with } \\
\text { internal cylinder }\end{array}$ & FVM & $\begin{array}{l}\text { Increasing Ra number leads } \\
\text { to an augmentation in } \mathrm{Nu}\end{array}$ & $\begin{array}{l}\text { It is obtained that minimum } \mathrm{Nu} \\
\text { is obtained when the cylinder } \\
\text { moved upward. It is } \\
\text { recommended to move } \\
\text { downward for better heat } \\
\text { transfer }\end{array}$ \\
\hline $\begin{array}{l}\text { Hosseinjani and } \\
\text { Nikfar [51] }\end{array}$ & $\begin{array}{l}\text { Unsteady free } \\
\text { convection }\end{array}$ & $\begin{array}{l}\text { Two-cylinder } \\
\text { inside rhombic } \\
\text { enclosure }\end{array}$ & $\begin{array}{l}\text { Immersed } \\
\text { boundary } \\
\text { scheme }\end{array}$ & $\begin{array}{l}\text { At low Ra, the nanofluid } \\
\text { had a negligible effect on } \\
\text { Nu. While at high } \mathrm{Ra}, \mathrm{Nu} \text { id } \\
\text { highly effected. }\end{array}$ & $\begin{array}{l}\text { The horizontal distance between } \\
\text { the circles effect on the } \\
\text { instability of the fluid flow }\end{array}$ \\
\hline $\begin{array}{l}\text { Dogonchi et al. } \\
\text { [53] }\end{array}$ & $\begin{array}{l}\text { Nanoparticle shape } \\
\text { (platelet, cylindrical } \\
\text { and spherical) effect } \\
\text { on heat transfer }\end{array}$ & $\begin{array}{l}\text { Cylinder in } \\
\text { partially thermal } \\
\text { active zone of } \\
\text { rhombus }\end{array}$ & CVFEM & $\begin{array}{l}\text { Rayleigh number and } \\
\text { nanofluid increasing helped } \\
\text { in improving } \mathrm{Nu}\end{array}$ & $\begin{array}{l}\text { Platelet shape gives better } \\
\text { performance }\end{array}$ \\
\hline
\end{tabular}

\section{Elliptical}

This section summarized the convection heat transfer due to the density difference between the inner body located within the elliptical enclosure [54-58] as shown in Fig. 7.

Sheikholeslami et al. [54] examined the natural convection between the inner elliptical body within a circular cylinder enclosure filled with nanofluid. The results explained that increasing Rayleigh number, nanoparticle, and inclination angle leads to an increase in the Nusselt number. Zhang et al. [55] investigated the natural convection between the hot elliptical inner body inside the cold square enclosure using a variational multiscale element scheme. The parameters were the major axis of the inner ellipse, Rayleigh number, and the inclination angle of the square enclosure. The results confirmed that inner body size, as well as the angle of inclination, had a noticeable impact on fluid flow. Sheikholeslami et al. [56] examined free convection, thermal radiation as well as a magnetic field between elliptical inner body within elliptical enclosure filled with nanofluid. Kefayati and Tang [57] examined numerically the inner cylinder or/and elliptical inner body inside a square enclosure by the lattice Boltzmann method. Abdulkadhim [58] demonstrated the free convection heat transfer within the elliptical enclosure with an inner circular cylinder. The gap was filled with nanofluid. The influence of the magnetic field, Rayleigh number, heat coefficient had been examined and addressed.

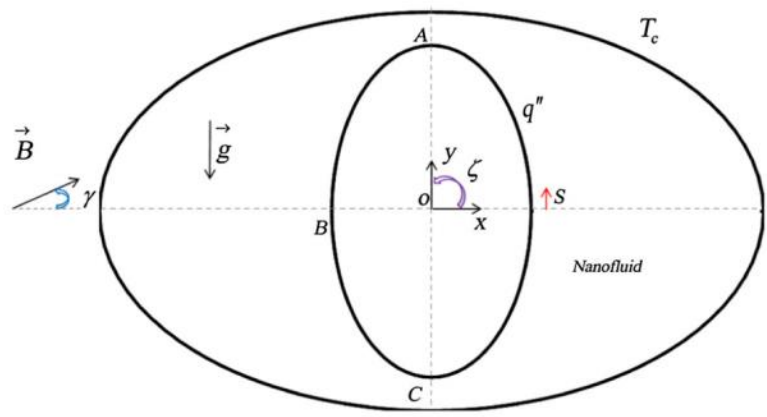

Figure 7. Schematic diagram of the inner body in an elliptical enclosure [56]

\section{Wavy enclosure}

This section summarized the convection heat transfer due to the density difference between the inner body located within wavy enclosure [24, 52, 58-62]. As an illustrative example for this case is indicated in Fig. 8.

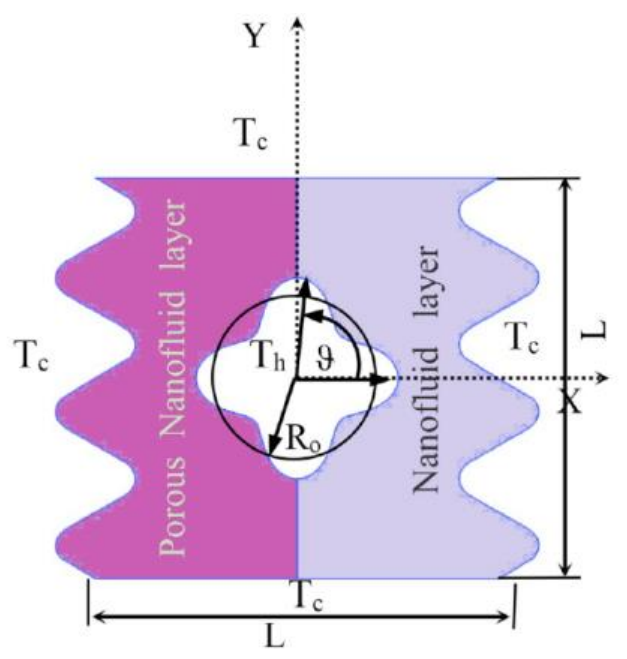

Figure 8. Schematic diagram of the inner body in an elliptical enclosure [62]

One of the interesting investigation that presented by Dogonchi [52] which concluded the inner rhombic body within wavy enclosure filled with $\mathrm{Fe}_{3} \mathrm{O}_{4}$. Control volume based upon the finite element method had been used in the simulation. Magnetic field dependent upon new viscosity model is employed. Many parameters had been included in the study like Rayleigh and Hartmann number, radiation parameters, aspect ratio, and nanoparticle shape factor (platelet, cylindrical, and spherical). The results highlighted that the increase of aspect ratio when the Hartmann number remains constant will reduce the rate of heat transfer. Jabbar et al. [59] examined the wavy interface on heat transfer between square enclosure divided into two layers, nanofluid/porous layer as well as a non-newtonian layer for various undulation number of wavy and Rayleigh numbers. Hatami and Safari [60] used the finite element method to solve the free convection between the circular cylinder inside the wavy nanofluid enclosure. Boulahia et al. [61] modeled the inner hot and cold cylinders inside the wavy enclosure. Abdulkadhim et al. [62] illustrated the multilayer system between the wavy inner cylinder within a wavy enclosure using a finite element scheme under various inner cylinder location and different undulations numbers. It can be seen in Table 6 which summarized the studies of elliptical and wavy enclosure with the internal body. 
Table 6 summarized the studies of natural convection between inner body within elliptical and wavy enclosure

\begin{tabular}{|c|c|c|c|c|c|}
\hline Ref & Objective & Enclosure shape & $\begin{array}{l}\text { Software/ } \\
\text { model used }\end{array}$ & Conclusions & Special findings \\
\hline $\begin{array}{l}\text { Sheikholeslam } \\
\text { i et al. [54] }\end{array}$ & $\begin{array}{l}\text { Natural convection } \\
\text { with nanofluid }\end{array}$ & $\begin{array}{l}\text { Circular enclosure } \\
\text { with inner elliptical } \\
\text { body }\end{array}$ & CVFEM & $\begin{array}{l}\text { Increasing of nanofluid } \\
\text { loading, Rayleigh number } \\
\text { and inclination angle } \\
\text { increases the Nusselt } \\
\text { number }\end{array}$ & $\begin{array}{l}\text { Increasing Ra reduces the } \\
\text { enhancement of heat transfer. }\end{array}$ \\
\hline $\begin{array}{l}\text { Zhang et al. } \\
\text { [55] }\end{array}$ & Natural convection & $\begin{array}{l}\text { Elliptical body } \\
\text { inside tilted square } \\
\text { enclosure }\end{array}$ & FEM & $\begin{array}{l}\text { The size of inner ellipse, as } \\
\text { well as } \mathrm{Ra} \text {, is highly } \\
\text { affected on } \mathrm{Nu}\end{array}$ & $\begin{array}{l}\text { The effect of inclination angle is } \\
\text { small on } \mathrm{Nu}\end{array}$ \\
\hline $\begin{array}{l}\text { Sheikholeslam } \\
\text { i et al. [56] }\end{array}$ & $\begin{array}{l}\text { Natural convective } \\
\text { flow, MHD, nanofluid }\end{array}$ & $\begin{array}{l}\text { Elliptical enclosure } \\
\text { with internal } \\
\text { elliptical body }\end{array}$ & CVFEM & $\begin{array}{l}\text { Increasing of the inclination } \\
\text { angle of the inner elliptical } \\
\text { body increases the heat } \\
\text { transfer rate }\end{array}$ & Derivation of formula of $\mathrm{Nu}$ \\
\hline $\begin{array}{l}\text { Kefayati and } \\
\text { Tang [57] }\end{array}$ & Natural convection & $\begin{array}{l}\text { Circle and elliptical } \\
\text { inner body inside } \\
\text { square enclosure }\end{array}$ & LBM & $\begin{array}{l}\text { Increasing the size of } \\
\text { cylinder augments the heat } \\
\text { transfer }\end{array}$ & $\begin{array}{l}\text { As Bingham number goes up, heat } \\
\text { transfer goes down }\end{array}$ \\
\hline $\begin{array}{l}\text { Abdulkadhim } \\
\text { [58] }\end{array}$ & $\begin{array}{l}\text { Natural convection, } \\
\text { MHD, heat } \\
\text { generation/absorption } \\
\text { and nanofluid }\end{array}$ & $\begin{array}{l}\text { Circular body in a } \\
\text { nanofluid elliptical } \\
\text { enclosure }\end{array}$ & FEM & $\begin{array}{l}\text { Hartmann number and } \mathrm{Ra} \\
\text { had an inverse effect on } \mathrm{Nu}\end{array}$ & $\begin{array}{l}\text { The change of inner cylinder } \\
\text { horizontally effect on the heat } \\
\text { transfer characteristics }\end{array}$ \\
\hline $\begin{array}{l}\text { Jabbar et al. } \\
\text { [59] }\end{array}$ & $\begin{array}{l}\text { Free convection with } \\
\text { wavy wall }\end{array}$ & $\begin{array}{l}\text { Square enclosure } \\
\text { with wavy wall }\end{array}$ & FEM & $\begin{array}{l}\text { Nu decreases as the power } \\
\text { index increases }\end{array}$ & Thickness layer effect on $\mathrm{Nu}$ \\
\hline $\begin{array}{l}\text { Hatami and } \\
\text { Safari [60] }\end{array}$ & $\begin{array}{l}\text { Natural convection } \\
\text { and nanofluid }\end{array}$ & $\begin{array}{l}\text { Internal cylinder } \\
\text { inside wavy } \\
\text { enclosure }\end{array}$ & FEM & $\begin{array}{l}\text { The location of inner } \\
\text { cylinder effect on heat } \\
\text { transfer }\end{array}$ & $\begin{array}{l}\text { The central location gives better } \\
\text { heat transfer characteristics }\end{array}$ \\
\hline $\begin{array}{l}\text { Boulahia et al. } \\
{[61]}\end{array}$ & Natural convection & $\begin{array}{l}\text { Cylinder inside } \\
\text { wavy enclosure }\end{array}$ & FVM & $\begin{array}{l}\text { Ra and nanofluid increasing } \\
\text { leads to increases the heat } \\
\text { transfer }\end{array}$ & $\begin{array}{l}\text { Increasing number of undulations } \\
\text { and reduction in the amplitude of } \\
\text { the wavy surface leads to } \\
\text { augmentation in heat transfer }\end{array}$ \\
\hline $\begin{array}{l}\text { Abdulkadhim } \\
\text { et al. [62] }\end{array}$ & $\begin{array}{l}\text { Natural convection } \\
\text { with multilayer } \\
\text { system }\end{array}$ & $\begin{array}{l}\text { Wavy internal body } \\
\text { within wavy } \\
\text { enclosure }\end{array}$ & COMSOL & $\begin{array}{l}\text { Number of corrugated effect } \\
\text { are small }\end{array}$ & $\begin{array}{l}\text { The inner body position effect on } \\
\text { heat and fluid flow }\end{array}$ \\
\hline
\end{tabular}

\section{Governing Equation}

Finally, it is important to insert the governing equations used in this specific subject of natural convection heat transfer within enclosure filled with pure fluid, porous medium, and nanofluid [63].

\subsection{Pure fluid}

$\frac{\partial U}{\partial X}+\frac{\partial V}{\partial Y}=0$

$U \frac{\partial U}{\partial X}+V \frac{\partial U}{\partial Y}=-\frac{\partial P}{\partial X}+\operatorname{Pr}\left(\frac{\partial^{2} U}{\partial X^{2}}+\frac{\partial^{2} U}{\partial Y^{2}}\right)$

$U \frac{\partial V}{\partial X}+V \frac{\partial V}{\partial Y}=-\frac{\partial P}{\partial Y}+\operatorname{Pr}\left(\frac{\partial^{2} V}{\partial X^{2}}+\frac{\partial^{2} V}{\partial Y^{2}}\right)+\operatorname{RaPr} \theta$

$U \frac{\partial \theta}{\partial X}+V \frac{\partial \theta}{\partial Y}=\frac{\partial^{2} \theta}{\partial X^{2}}+\frac{\partial^{2} \theta}{\partial Y^{2}}$

\subsection{Porous Medium}

$\frac{\partial U}{\partial X}+\frac{\partial V}{\partial Y}=0$

$\frac{\partial U}{\partial Y}=-\frac{K}{\mu} \frac{\partial^{2} P}{\partial X \partial Y}$ $\frac{\partial V}{\partial X}=-\frac{K}{\mu} \frac{\partial^{2} P}{\partial X \partial Y}+R a \frac{\partial T}{\partial X}$

$U \frac{\partial \theta}{\partial X}+V \frac{\partial \theta}{\partial Y}=\frac{\partial^{2} \theta}{\partial X^{2}}+\frac{\partial^{2} \theta}{\partial Y^{2}}$

\subsection{Nanofluid}

$$
\begin{gathered}
\frac{\partial U}{\partial X}+\frac{\partial V}{\partial Y}=0 \\
\rho_{n f}\left(U \frac{\partial U}{\partial X}+V \frac{\partial U}{\partial Y}\right)=-\frac{\partial P}{\partial X}+\mu_{n f}\left(\frac{\partial^{2} U}{\partial X^{2}}+\frac{\partial^{2} U}{\partial Y^{2}}\right) \\
\rho_{n f}\left(U \frac{\partial U}{\partial X}+V \frac{\partial U}{\partial Y}\right)=-\frac{\partial P}{\partial Y}+\mu_{n f}\left(\frac{\partial^{2} V}{\partial X^{2}}+\frac{\partial^{2} V}{\partial Y^{2}}\right) \\
+g\left[(1-\varphi)(\rho \beta)_{b f}+\varphi(\rho \beta)_{S}\right]\left(T-T_{c}\right) \\
U \frac{\partial \theta}{\partial X}+V \frac{\partial \theta}{\partial Y}=\alpha_{n f}\left(\frac{\partial^{2} \theta}{\partial X^{2}}+\frac{\partial^{2} \theta}{\partial Y^{2}}\right)
\end{gathered}
$$

\section{Conclusion}

This paper presents a comprehensive literature review of the most published papers in the field of natural convection between inner bodies located inside different complex enclosure shapes. The main conclusions are: 
- The inner bodies inside trapezoidal, parallelogrammic enclosure are very limited, and more investigation should be done.

- The studies regarding wavy enclosure are limited in a comparison with other simple shapes of enclosure despite its important applications is electronic equipment.

- There are limitations in the studies of natural convection between the inner body located in a wavy enclosure.

- Multi-layers system inside a wavy enclosure is limited as most of the recent studies focus on nanofluid, porous media filled the enclosure but there are serious limitations when the nanofluid/porous media filled the space.

- Dufour and Soret effect on natural flow for the multi-layer system are not investigated yet in full-details.

\section{ACKNOWLEDGMENT}

We would like to thank our institutions (Al-Mustaqbal University College and Al-Qadisiyah University) for their supports and for giving us the time for writing and completing the present article review.

\section{REFERENCES}

[1] R.S. Kaluri, T. Basak, Analysis of distributed thermal management policy for energy-efficient processing of materials by natural convection, Energy, 35(12) (2010) 5093-5107.

[2] B. Ghasemi, S. Aminossadati, A. Raisi, Magnetic field effect on natural convection in a nanofluid-filled square enclosure, International Journal of Thermal Sciences, 50(9) (2011) 1748-1756.

[3] F.-H. Lai, Y.-T. Yang, Lattice Boltzmann simulation of natural convection heat transfer of Al2O3/water nanofluids in a square enclosure, International journal of thermal sciences, 50(10) (2011) 1930-1941.

[4] M. Bhuvaneswari, S. Sivasankaran, Y. Kim, Magnetoconvection in a square enclosure with sinusoidal temperature distributions on both side walls, Numerical Heat Transfer, Part A: Applications, 59(3) (2011) 167-184.

[5] P. Alam, A. Kumar, S. Kapoor, S. Ansari, Numerical investigation of natural convection in a rectangular enclosure due to partial heating and cooling at vertical walls, Communications in Nonlinear Science and Numerical Simulation, 17(6) (2012) 2403-2414

[6] M.A. Teamah, A.F. Elsafty, E.Z. Massoud, Numerical simulation of doublediffusive natural convective flow in an inclined rectangular enclosure in the presence of magnetic field and heat source, International journal of thermal sciences, 52 (2012) 161-175.

[7] A. Chamkha, Hydromagnetic double-diffusive convection in a rectangular enclosure with linearly heated and concentrated wall (s) in the presence of heat generation/absorption effects, (2012).

[8] Y. Bakhshan, H. Ashoori, Analysis of a fluid behavior in a rectangular enclosure under the effect of magnetic field, World Academy of Science, Engineering and Technology, 61 (2012) 637-641.

[9] H. El Qarnia, A. Draoui, E. Lakhal, Computation of melting with natural convection inside a rectangular enclosure heated by discrete protruding heat sources, Applied Mathematical Modelling, 37(6) (2013) 3968-3981.

[10] M.K. Moraveji, M. Hejazian, Natural convection in a rectangular enclosure containing an oval-shaped heat source and filled with Fe3O4/water nanofluid, International communications in heat and mass transfer, 44 (2013) 135-146.

[11] G. Bourantas, V. Loukopoulos, MHD natural-convection flow in an inclined square enclosure filled with a micropolar-nanofluid, International Journal of Heat and Mass Transfer, 79 (2014) 930-944.

[12] F. Selimefendigil, H.F. Öztop, K. Al-Salem, Natural convection of ferrofluids in partially heated square enclosures, Journal of magnetism and magnetic materials, 372 (2014) 122-133.

[13] M. Bouhalleb, H. Abbassi, Natural convection in an inclined rectangular enclosure filled by $\mathrm{CuO}-\mathrm{H} 2 \mathrm{O}$ nanofluid, with sinusoidal temperature distribution, International Journal of Hydrogen Energy, 40(39) (2015) 1367613684.

[14] N. Biswas, P.S. Mahapatra, N.K. Manna, P.C. Roy, Influence of heater aspect ratio on natural convection in a rectangular enclosure, Heat Transfer Engineering, 37(2) (2016) 125-139.

[15] N. Nithyadevi, V. Divya, M. Rajarathinam, Effect of Prandtl number on natural convection in a rectangular enclosure with discrete heaters, J. Apple. SCI. Eng, 20(2) (2017) 173-182.

[16] C. Qi, G. Wang, L. Yang, Y. Wan, Z. Rao, Two-phase lattice Boltzmann simulation of the effects of base fluid and nanoparticle size on natural convection heat transfer of nanofluid, International Journal of Heat and Mass Transfer, 105 (2017) 664-672.

[17] K. Al-Farhany, A. Abdulkadhim, Numerical investigation of conjugate natural convection heat transfer in a square porous cavity heated partially from left sidewall, International journal of heat and technology, 36(1) (2018) 237-244.

[18] S. Dutta, A.K. Biswas, S. Pati, Natural convection heat transfer and entropy generation inside porous quadrantal enclosure with nonisothermal heating at the bottom wall, Numerical Heat Transfer, Part A: Applications, 73(4) (2018) 222240.

[19] M. Torki, N. Etesami, Experimental investigation of natural convection heat transfer of SiO 2/water nanofluid inside inclined enclosure, Journal of Thermal Analysis and Calorimetry, 139(2) (2020) 1565-1574.

[20] A. Graževičius, A. Kaliatka, E. Ušpuras, Numerical investigation of two-phase natural convection and temperature stratification phenomena in a rectangular enclosure with conjugate heat transfer, Nuclear Engineering and Technology, 52(1) (2020) 27-36.

[21] A.-M. Barik, K. Al-Farhany, Numerical Investigation of the Effect of Baffle Inclination Angle on Nanofluid Natural Convection Heat Transfer in A Square Enclosure, Al-Qadisiyah Journal for Engineering Sciences, 12(2) (2019) 61-71.

[22] M. Sheikholeslami, A.J. Chamkha, Flow and convective heat transfer of a ferronanofluid in a double-sided lid-driven cavity with a wavy wall in the presence of a variable magnetic field, Numerical Heat Transfer, Part A: Applications, 69(10) (2016) 1186-1200.

[23] M. Sheikholeslami, P. Rana, S. Soleimani, Numerical study of MHD natural convection liquid metal flow and heat transfer in a wavy enclosure using CVFEM, Heat Transfer Research, 48(2) (2017).

[24] T.A. Alkanhal, M. Sheikholeslami, M. Usman, R.-u. Haq, A. Shafee, A.S. AlAhmadi, I. Tlili, Thermal management of MHD nanofluid within the porous medium enclosed in a wavy shaped cavity with square obstacle in the presence of radiation heat source, International Journal of Heat and Mass Transfer, 139 (2019) 87-94.

[25] Q. Xiong, E. Abohamzeh, J.A. Ali, S.M. Hamad, I. Tlili, A. Shafee, H. Habibeh, T.K. Nguyen, Influences of nanoparticles with various shapes on MHD flow inside wavy porous space in appearance of radiation, Journal of Molecular Liquids, 292 (2019) 111386.

[26] J. Lee, M. Ha, H. Yoon, Natural convection in a square enclosure with a circular cylinder at different horizontal and diagonal locations, International Journal of Heat and Mass Transfer, 53(25-26) (2010) 5905-5919.

[27] S.H. Hussain, A.K. Hussein, Numerical investigation of natural convection phenomena in a uniformly heated circular cylinder immersed in square enclosure filled with air at different vertical locations, International Communications in Heat and Mass Transfer, 37(8) (2010) 1115-1126.

[28] Y.G. Park, H.S. Yoon, M.Y. Ha, Natural convection in square enclosure with hot and cold cylinders at different vertical locations, International Journal of Heat and Mass Transfer, 55(25-26) (2012) 7911-7925.

[29] F. Ali, D. Maki, M. Abed, Numerical Investigation of Mixed Convection by NonConcentric Positions of Rotating Circular Cylinder in Square Enclosure, (2018). 
[30] R. Roslan, H. Saleh, I. Hashim, A. Bataineh, Natural convection in an enclosure containing a sinusoidally heated cylindrical source, International Journal of Heat and Mass Transfer, 70 (2014) 119-127.

[31] Z. Huang, W. Zhang, G. Xi, Natural convection in square enclosure induced by inner circular cylinder with time-periodic pulsating temperature, International Journal of Heat and Mass Transfer, 82 (2015) 16-25.

[32] X. Xu, Z. Yu, Y. Hu, L. Fan, K. Cen, A numerical study of laminar natural convective heat transfer around a horizontal cylinder inside a concentric air-filled triangular enclosure, International journal of heat and mass transfer, 53(1-3) (2010) 345-355

[33] Z.-T. Yu, Y.-C. Hu, L.-W. Fan, K.-F. Cen, A parametric study of Prandtl number effects on laminar natural convection heat transfer from a horizontal circular cylinder to its coaxial triangular enclosure, Numerical Heat Transfer, Part A: Applications, 58(7) (2010) 564-580.

[34] F. Selimefendigil, H.F. Öztop, MHD mixed convection of nanofluid filled partially heated triangular enclosure with a rotating adiabatic cylinder, Journal of the Taiwan Institute of Chemical Engineers, 45(5) (2014) 2150-2162.

[35] Z.-T. Yu, X. Xu, Y.-C. Hu, L.-W. Fan, K.-F. Cen, Unsteady natural convection heat transfer from a heated horizontal circular cylinder to its air-filled coaxial triangular enclosure, International Journal of Heat and Mass Transfer, 54(7-8) (2011) 1563-1571

[36] Y.-f. Wang, X. Xu, T. Tian, L.-w. Fan, W.-1. Wang, Z.-t. Yu, Laminar mixed convection heat transfer of SiC-EG nanofluids in a triangular enclosure with a rotating inner cylinder: simulations based on the measured thermal conductivity and viscosity, Journal of Zhejiang University-SCIENCE A, 16(6) (2015) 478490.

[37] E. Sourtiji, D. Ganji, S. Seyyedi, Free convection heat transfer and fluid flow of $\mathrm{Cu}$-water nanofluids inside a triangular-cylindrical annulus, Powder Technology, 277 (2015) 1-10.

[38] A.I. Amrani, N. Dihmani, S. Amraqui, A. Mezrhab, Combined Natural Convection and Thermal Radiation Heat Transfer in a Triangular Enclosure with an Inner Rectangular Body, in: Defect and diffusion forum, Trans Tech Publ, 2018, pp. 49-68

[39] A.K. Hussein, H.K. Hamzah, F.H. Ali, L. Kolsi, Mixed convection in trapezoidal enclosure filled with two layers of nanofluid and porous media with a rotating circular cylinder and a sinusoidal bottom wall, Journal of Thermal Analysis and Calorimetry, (2019) 1-19.

[40] A. Esam M, A. Abdulkadhim, R.A. Hamzah, H.K. Hamzah, F.H. Ali, Natural Convection Heat Transfer for Adiabatic Circular Cylinder Inside Trapezoidal Enclosure Filled with Nanofluid Superposed Porous-Nanofluid Layer, FME Transactions, 48(1) (2020) 83.

[41] M. Khan, A.A. Khan, M.N. Hasan, Numerical study of mixed convection heat transfer from a rotating cylinder inside a trapezoidal enclosure, in: AIP Conference Proceedings, AIP Publishing LLC, 2016, pp. 050036.

[42] F. Selimefendigil, Natural convection in a trapezoidal cavity with an inner conductive object of different shapes and filled with nanofluids of different nanoparticle shapes, Iranian Journal of Science and Technology, Transactions of Mechanical Engineering, 42(2) (2018) 169-184.

[43] S.Y. Ahmed, F.H. Ali, H.K. Hamzah, Heatlines visualization of natural convection in trapezoidal cavity filled with nanofluid and divided by porous medium partition, Computers \& Fluids, (2018).

[44] A.K. Hussein, Computational analysis of natural convection in a parallelogrammic cavity with a hot concentric circular cylinder moving at different vertical locations, International communications in heat and mass transfer, 46 (2013) 126-133.

[45] H.S. Majdi, A. Abdulkadhim, A.M. Abed, Numerical investigation of natural convection heat transfer in a parallelogramic enclosure having an inner circular cylinder using liquid nanofluid, Frontiers in Heat and Mass Transfer, 2019, in, DOI, 2019.

[46] A. Chamkha, Conduction-combined forced and natural convection in a lid-driven parallelogram-shaped enclosure divided by a solid partition, (2012).
[47] A. Baïri, Transient free convection in passive buildings using 2D air-filled parallelogram-shaped enclosures with discrete isothermal heat sources, Energy and buildings, 43(2-3) (2011) 366-373.

[48] S.H. Hussain, A.K. Hussein, K.A. Kadim, Numerical Simulation of Natural Convection in a Parallelogrammic Enclosure Containing Volumetric Heat Source with Non - uniformly Heated Left Sidewall, Heat Transfer-Asian Research, 43(6) (2014) 542-560

[49] R. Anandalakshmi, T. Basak, Numerical simulations for the analysis of entropy generation during natural convection in porous rhombic enclosures, Numerical Heat Transfer, Part A: Applications, 63(4) (2013) 257-284.

[50] C. Choi, S. Jeong, M.Y. Ha, H.S. Yoon, Effect of a circular cylinder's location on natural convection in a rhombus enclosure, International Journal of Heat and Mass Transfer, 77 (2014) 60-73.

[51] A.A. Hosseinjani, M. Nikfar, Numerical analysis of unsteady natural convection from two heated cylinders inside a rhombus enclosure filled with $\mathrm{Cu}$-water nanofluid, International Communications in Heat and Mass Transfer, 113 (2020) 104510 .

[52] A. Dogonchi, Heat transfer by natural convection of Fe3O4-water nanofluid in an annulus between a wavy circular cylinder and a rhombus, International Journal of Heat and Mass Transfer, 130 (2019) 320-332

[53] A. Dogonchi, M. Waqas, D. Ganji, Shape effects of Copper-Oxide (CuO) nanoparticles to determine the heat transfer filled in a partially heated rhombus enclosure: CVFEM approach, International Communications in Heat and Mass Transfer, 107 (2019) 14-23.

[54] M. Sheikholeslami, R. Ellahi, M. Hassan, S. Soleimani, A study of natural convection heat transfer in a nanofluid filled enclosure with elliptic inner cylinder, International Journal of Numerical Methods for Heat \& Fluid Flow, (2014).

[55] P. Zhang, X. Zhang, J. Deng, L. Song, A numerical study of natural convection in an inclined square enclosure with an elliptic cylinder using variational multiscale element free Galerkin method, International Journal of Heat and Mass Transfer, 99 (2016) 721-737.

[56] M. Sheikholeslami, T. Hayat, A. Alsaedi, On simulation of nanofluid radiation and natural convection in an enclosure with elliptical cylinders, International Journal of Heat and Mass Transfer, 115 (2017) 981-991.

[57] G.R. Kefayati, H. Tang, Lattice Boltzmann simulation of viscoplastic fluids on natural convection in an inclined enclosure with inner cold circular/elliptical cylinders (Part I: One cylinder), International journal of heat and mass transfer, 123 (2018) 1138-1162.

[58] A. Abdulkadhim, On Simulation of the Natural Convection Heat Transfer Between Circular Cylinder and an Elliptical Enclosure Filled with Nanofluid [Part I: The Effect of MHD and Internal Heat Generation/Absorption], Mathematical Modelling of Engineering Problems, (2019).

[59] M.Y. Jabbar, S.Y. Ahmed, H. Hamazh, F.H. Ali, S.O.W. Khafaji, Effect of layer thickness on natural convection in a square enclosure superposed by nano-porous and non-newtonian fluid layers divided by a wavy permeable wall, Int. J. Mech. Mechatron. Eng, 19(03) (2019).

[60] M. Hatami, H. Safari, Effect of inside heated cylinder on the natural convection heat transfer of nanofluids in a wavy-wall enclosure, International Journal of Heat and Mass Transfer, 103 (2016) 1053-1057.

[61] Z. Boulahia, A. Wakif, R. Sehaqui, Modeling of free convection heat transfer utilizing nanofluid inside a wavy enclosure with a pair of hot and cold cylinders, Frontiers in Heat and Mass Transfer (FHMT), 8 (2017).

[62] A. Abdulkadhim, H.K. Hamzah, F.H. Ali, A.M. Abed, I.M. Abed, Natural convection among inner corrugated cylinders inside wavy enclosure filled with nanofluid superposed in porous-nanofluid layers, International Communications in Heat and Mass Transfer, 109 (2019) 104350.

[63] D. Das, M. Roy, T. Basak, Studies on natural convection within enclosures of various (non-square) shapes-A review, International Journal of Heat and Mass Transfer, 106 (2017) 356-406 